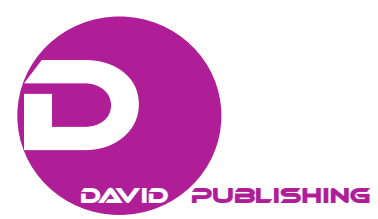

\title{
Roadmap for Data-Driven Real Estate Management in the Municipality of Groningen
}

\author{
Sanne Anouk Lubbers \\ Citytalent Real Estate Municipality of Groningen, the Netherlands \\ Jan Veuger \\ Saxion University of Applied Sciences, Enschede, the Netherlands \\ Hanze University of Applied Sciences, Groningen, the Netherlands
}

\begin{abstract}
In order to achieve its objectives and to handle its real estate in a professional manner, the real estate company of the municipality of Groningen would like to begin managing the social real estate portfolio in an innovative way. The use of data and information technologies, or data-driven working and managing, provides insight into the effectiveness and efficiency of the portfolio. This roadmap includes, in addition to a theoretical framework, a step-by-step plan describing the process towards data-driven real estate management. The starting point here is to invent step by step, because data-driven real estate management requires a different way of thinking and doing. Actionable insights are created so that strategic management becomes possible. The data model to be developed forms the basis for entering into dialogue, taking decisions and drawing up long-term goals. The outcome is a data model for a proactive, agile, future-proof organization that is capable of responding to a changing environment and manages for the highest possible social return. ${ }^{1}$
\end{abstract}

Keywords: data, real estate, municipal, process, roadmap, social return

\section{Introduction}

The rise of Big Data and especially Smart Data enables us to gain insight in a different way into what will happen in the future and to manage accordingly. Smart Cities, smart devices, and other examples of the Internet of Things - not only people are online, but also things - generate valuable data and make this data easy to share. And the introduction of Blockchain in real estate, for example, provides a different way of transferring value (Veuger, 2017). These are examples of the use of data and technological capabilities that result in major changes and have an influence on and potential value for-more transparent, professional, objective - the real estate world. But how can the municipality of Groningen use new data and information technologies to strategically manage the social real estate portfolio?

Sanne Anouk Lubbers, M.Sc., Citytalent Real Estate Municipality of Groningen, the Netherlands.

Jan Veuger, MRE, Ph.D., FRICS, professor, Blockchain of the School of Finance \& Accounting, School of Creative Technology and School of Governance, Law and Urban Development of the Saxion University of Applied Sciences, Enschede (2019); professor, Real Estate, Hanze University of Applied Sciences, Groningen, the Netherlands (2002-2019).

Correspondence concerning this article should be addressed to Jan Veuger, Law and Urban Development, Creative Technology and School of Governance, Schools of Finance \& Accounting, Saxion University of Applied Sciences, P. O. Box 70.000, 7500 KB, Enschede, the Netherlands. Email: j.veuger@ saxion.nl.

${ }^{1}$ The article was partly realized through the efforts of Paul Oortwijn, director of Vastgoedbedrijf of the municipality of Groningen. 


\section{Ambition}

The municipality of Groningen owns and uses a (social) real estate portfolio to achieve social objectives. In addition, there are financial and programme objectives from a more business-economic perspective. Real estate is thus a means to connect people or to make movement and fulfilment possible for everyone (social), but real estate is also part of the sustainability ambition and austerity task (financial and implementation). The real estate company of the municipality of Groningen (hereinafter: the Vastgoedbedrijf) facilitates and has the task of providing central insight and guidance to the social real estate portfolio. Also important here is determining a direction for the long term, making choices and allocating resources. There has long been the realization that a more professional way of managing is necessary (Veuger, 2013). Strategic portfolio management is nothing other than managing on effectiveness (To what extent does the real estate contribute to the primary goals?) and efficiency (How well does the real estate do this?) (Wildenberg, 2017). The Vastgoedbedrijf wants to do this by using data and information technologies in a different (innovative) way. The ambition can be defined as follows: The Vastgoedbedrijf wants to deploy data-driven management on the property portfolio so that social, financial and programme objectives are achieved in a professional manner (i.e., effectively and efficiently deal with social real estate).

With data-driven management, the guiding action is meant to be based on the systematic collection, management, analysis and interpretation of data that meets the definition of the VNG (VNG, 2018). It is about the right combination of data, technology, and knowledge. Data can be converted to information with the right technology. By placing this information in its context, connections can be made, and the information becomes meaningful. Knowledge arises, and knowledge ultimately leads to valuable insights and makes acting (managing) possible.

The use of data and information technologies can provide insight into effectiveness and efficiency, but this does not happen automatically. Figure 1 shows the path that is needed to arrive at insights that make actions possible (actionable insights).

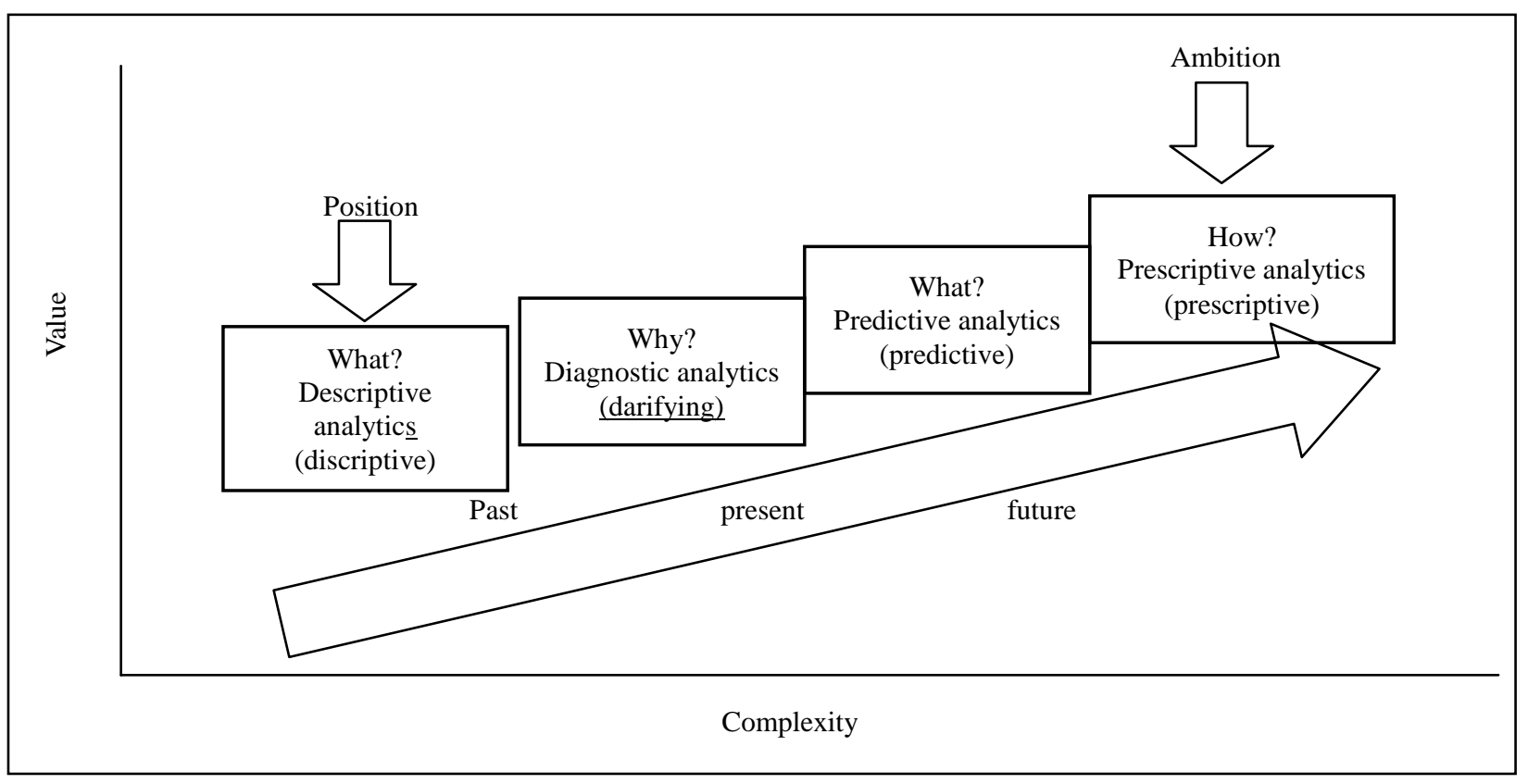

Figure 1. Path to actionable insights (own translation of Gartner). 
The municipality of Groningen is still mainly in the descriptive phase, both organization-wide and within the Vastgoedbedrijf. Data currently helps us to show what has happened. It provides insight, for example if the data show that there is a negative financial return (execution level) or a decline in the number of children moving (policy level). In order to be able to subsequently explain this, the "why" must be examined (diagnostic analytics). Is the rental price not sufficient to cover the cost price and/or are the maintenance costs too high? Or in the second case: Is the distance to the closest sports facility too large or does the offer not match the target group? Ultimately, we want to know, via the path of the what and the why, where we should go and how we can get there. We are not faced with surprises, we know what the future will bring (predictive analytics), and we can influence that future (prescriptive analytics).

\section{Process}

The path to data-driven real estate management is a process that benefits from a step-by-step plan. The step-by-step plan follows the simple principles of planning, experimenting, evaluating, and reacting, i.e., the Plan, Do, Check, and Act cycle (PDCA cycle) of Deming. In fact, the municipality of Groningen is at the beginning of the second step without the first step actually being completed. This fits within a dynamic process of change and improvement also known as respectively Agile and Lean (Both are philosophies with which flexible control and implementation can be given to projects).

An important point to note is that, within the process, a strong appeal is made to step-by-step inventions. A different way of thinking and doing without an exact picture of the final goal is a process of discovery. After all, the classic data-information process is characterized by the unlocking of data and then turning it into an information product. The (future) user is able to indicate what his requirements and wishes are and has an idea of the end product. This is not necessarily the case in the case of data-driven real estate management (Damhof, 2016). A starting point from the Vastgoedbedrijf can be given in broad strokes. Using performance indicators and activity drivers, the management information required at minimum can be indicated (see Figure 2 under step 2). Performance indicators show whether a goal has been achieved; they give an outcome-the match between performance and goal— based on the past. To be able to manage, insight is also needed into which factors influence the outcome, the activity drivers. Activity drivers give insight into the intermediate process and are the knobs that can be turned. In the example of the financial return, the rental income, maintenance costs, and energy consumption, among other things, are factors that affect this. Monitoring these drivers provides valuable management information on the efficiency of the real estate. At the same time, you also want information about the effectiveness, and ultimately, a more predictive model with, for example, scenario sketching is needed. The knobs and other requirements and wishes gradually have to take shape through the process, and at the same time, the insights gained on the basis of data change this.

\section{Step 1: Plan}

Before the path to actionable insights can be travelled at all, it is important to see what data and data analysis can add to policy and implementation and to have a vision for data and digitization. Above all, (political) agenda placement and determining a direction are important. The municipality of Groningen recognizes the value of data, and we are aware of the potential of data-driven work and management. There is a vision (Virtueel Groningen 2022, Gemeente Groningen, 2017), and strengths are bundled both internally between departments and externally with, for example, the CBS in the Urban Data Centre or the University of 
Groningen in the Urban Gro Lab. The vision indicates where we want to go (including data-driven work and management) but not how we get there and when we have to do something. In order to make the vision for digitization usable for this roadmap, we have made our own translation into social real estate, which in our opinion amounts to the following starting points:

(1) Social returns are achieved through customization in the sense that, for example, the needs in a neighbourhood or wishes of the user are matched (the match between supply and demand).

(2) Customization is possible if trends, patterns, needs, and wishes are clear and monitored.

(3) With monitoring, there is the ability to adjust and respond to changes and trends. In addition to a flexible organization, this also requires flexible real estate. This is a challenge, since a municipal organization is typically less agile (among other things due to political and policy cycles) and, for example, decisions in real estate have a longer time horizon. The organization must be able to act on insights gained, but the real estate itself must also be able to move accordingly. Examples are multifunctional use, other forms of leases and redividability, but also the reuse of materials through a building passport.

(4) Data is created by monitoring, and this data must be standardized and made available in a central location, for example in the form of a single digital model of the city. Transparency about which data is used in what way and why is important here (Kool, Timmer, \& Est, 2015).

(5) Residents/users are more often and more easily accessible via digital channels. We believe that there are two sides to this. On the one hand, this facilitates the collection of data and the delivery of customization. On the other hand, the question arises of whether all the physical real estate $\left(\mathrm{m}^{2}\right)$ is still necessary if almost everyone can reach, question, and engage each other digitally (owner-user, government-citizen, and resident-resident).

(6) Real estate has a facilitating role; it is about providing a service. As a result, in theory, ownership of real estate may not always be necessary.

(7) The use of external data/Big Data (CBS, Land Registry, and other data sources) is necessary to sketch a complete picture and to be able to interpret (the municipality's own) data. Big Data has many definitions, but it is characterized in any case by the analysis of large quantities of rapidly changing, complex data using new techniques. It can be seen as a unique mechanism that can interpret the world around us and enables us to make predictions (Klous \& Wielaard, 2014).

(8) Innovative initiatives must be developed and/or connected with initiatives such as sensoring (Internet of Things (IoT)), data analytics (data lab, data mining, and machine learning) and Blockchain. Machine learning is a technique with which computers are able to learn from known and new data without having been programmed by humans with that data. Inputs and outputs are linked together, and patterns are discovered. Blockchain is a technology that enables transactions of validated data without the intervention of third parties. Veuger (2017) did an exploration of the potential disruptive effect of this on real estate. An innovation lab such as that of the Hanze University of Applied Sciences or the challenges as set out in the Startup in Residence programme - a collaboration between the government and start-ups - offers space to develop these and other initiatives and to come to solutions together.

(9) Innovative initiatives must have a platform, and there must be an organization and environment where there is room for experiments and making mistakes. One type of experiment that can be used in the long term-for example in step 4-is the living lab, a lifelike experimental environment for testing solutions (Est et al., 2018). The Urban Gro Lab is the experimental garden of the city of Groningen. 
(10) The collaboration must be sought both internally and externally, so that flexible knowledge networks are created. Internal agenda-setting and coalition building but also cooperation with knowledge institutions such as the University of Groningen, Hanze University of Applied Sciences, and IT Academy North Netherlands, as well as market parties as described in both previous action points, is valuable.

Data-driven working and managing is not an end in itself but a means to the higher goal. Ultimately, it is about creating the highest possible social return. Social return is the ratio between investment in money, people and resources on the one hand and social impact on the other. Which social effects must be achieved with the social real estate and whether these are achieved are up to the management and the policy departments/programmes (effectiveness). It is up to the Vastgoedbedrijf to say something about money and resources (efficiency).

Stakeholder for this first step is the entire organization with the conditions of investing in data governance (vision, rules) and collaboration.

\section{Step 2: Do, Data-Driven Work}

The next step is not to keep thinking about the possibilities, but to start doing. Nobody knows what exactly is possible and what the exact outcome should be, but it is, as stated, step-by-step invention. Here the step is taken towards data-driven work. A condition for this is of course that the data is available and usable, in other words that the basis is in order. At the same time, the changes and developments happen so quickly that having and knowing everything in advance is no longer realistic. By experimenting, we learn, and that is what is already happening in many places within the organization. Specifically focused on real estate, at least the following tracks are currently focused on collecting and organizing data:

- Setting up financial module DaFinci (Vastgoedbedrijf)

- Municipal benchmark (Vastgoedbedrijf and TIAS Business School)

- Determining and understanding critical performance indicators and activity drivers (Vastgoedbedrijf)

- Monitoring energy consumption via smart meters (Gresco)

- Leesman: research on workplace effectiveness and user-friendly municipal buildings (Vastgoedbedrijf and SSC Facilitaire Services \& Huisvesting)

- Stadskompas/basic monitor (Directie Maatschappelijke Ontwikkeling/Stadsontwikkeling)

- Urban Data Centre (Onderzoek, Informatie, \& Statistiek and CBS)

- Concretizing the city (Geo-information and Land Registry)

- Monitoring Kardinge (Sport050)

Data makes it possible to make factual statements about and to be able to manage on effectiveness and efficiency — or the social return — of the real estate portfolio. The idea is to start by measuring the portfolio performance using the four indicators as shown in Figure 2. Per indicator, examples of performances that are measured are given. The list is not fixed or exhaustive, but is a reflection of the need as it exists within the municipality of Groningen. It is conceivable and even desirable that new performance indicators are gradually added as befit a dynamic process.

Data visualization of the performance indicators in the form of a digital dashboard is a tangible first step. With regard to a number of indicators and especially at the strategic level, useful data is already available, so what is available is used as a start. A tool is created that can be connected. Precisely because the developments of, for example, data inventory and collection (IoT) happen so quickly, space must be left for adding new 
insights and systems. The development and roll-out takes place in the form of a project with the help of at least an information advisor and data analyst. In this step, data is converted to information.

\begin{tabular}{|c|c|c|}
\hline \multirow[b]{2}{*}{ 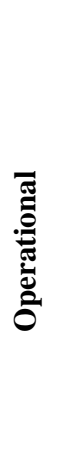 } & Policy & Real Estate \\
\hline & $\begin{array}{l}\text { Policy indicators } \\
\text { Public propose } \\
\text { Reachability } \\
\text { Accessibility } \\
\text { Quality } \\
\text { Development opportunity } \\
\text { (location) }\end{array}$ & $\begin{array}{l}\text { Financial indicators } \\
\text { Financial returns/ } \\
\text { cost-covering } \\
\text { Development opportunity } \\
\text { (building) } \\
\text { Sustainability }\end{array}$ \\
\hline \multirow[t]{2}{*}{ 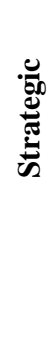 } & $\begin{array}{l}\text { Use indicators } \\
\text { Occupancy } \\
\text { User satisfaction }\end{array}$ & $\begin{array}{l}\text { Building indicators } \\
\text { Technical condition } \\
\text { Maintenance costs } \\
\text { Energy consumption }\end{array}$ \\
\hline & EFFECT & INVESTMENT \\
\hline
\end{tabular}

Figure 2. Performance indicators by level and expertise (own translation of BBN advisors/VastgoedMaps and Republiq).

An important point to note here is that although this appears to be a more technical exercise, step 2 (and step 3) should be seen as a joint learning process. The steps provide the opportunity to practise with evidence-based thinking, working, and deciding. We learn to further develop the capabilities of data and information technologies; that is, it makes us more data-literate. The complexity and unpredictability of both the material and the data model require a high change capacity. The change strategy that is best suited in this case is the interactive strategy according to the Boonstra model (2017). Characteristic of this form is the interactive exchange of knowledge and ideas on the basis of imagination and vision of the future.

A final comment is that there must also be explicit attention to what is permitted (legal) and what the municipality of Groningen wants (ethics). In terms of legality, every municipality (and other parties) must comply with laws such as the General Data Protection Regulation (GDPR). It must be clear what data the municipality may request, store, and use so that it is clear that the desired and intended data is also usable data. In line with this, there is also the importance of data ownership. It must be clear who is legitimately the owner so that responsibility and quality are guaranteed. In addition to legislation, ethics also plays an important role in the handling of data and information techniques. Schäfer $(2017)^{2}$ notes that it is good that decisions are made on the basis of verifiable facts, but at the same time warn against the apparent objectivity offered by data, data analysis and visualization. It is up to us to handle data ethically and, for example, to use value-free assumptions (containing no value judgment) and to prevent stigmatization (branding of groups and/or individuals) (Feenstra, 2018).

\footnotetext{
${ }^{2}$ https://pure.uva.nl/ws/files/25653424/624771.pdf
} 
Stakeholders for this second step are Vastgoedbedrijf, Directie Maatschappelijke Ontwikkeling, Stadsontwikkeling, Onderzoek, Informatie \& Statistiek, Geo-information, and external parties. Conditions are then basically in order (including DaFinci), investing in data infrastructure (Datawarehouse), investing in data skills (data analyst) and data literacy, attention to legal and ethical issues, and collaborating with internal and external parties.

\section{Step 3: Check}

This phase is twofold. On the one hand, it is a more data-technical evaluation. Do we have the right data at our disposal? Are the data linked to each other in the right way? And may we and do we want to use the data in this way? The result of this step may be that, for example, a different method of data collection or additional data is required. You go back to the previous step, in the sense of an upward spiral. Certainly in the beginning, there are relatively short sprints of experimenting, evaluating, and adjusting. On the other hand, it is also a more data-analytical evaluation. It is about the insights that can be extracted from the data, or about giving meaning to the outcomes by combining data and knowledge. Here, the leap is made from descriptive to diagnostic analytics (Figure 1). Through the performance indicators and activity drivers, patterns and developments become visible. Here, what is happening becomes clear, and an answer can be given to the question of whether we are dealing with our real estate portfolio in the right way.

Stakeholders for this third step are in any case Vastgoedbedrijf, Directie Maatschappelijke Ontwikkeling, Stadsontwikkeling and Onderzoek, Informatie \& Statistiek. Condition is investing in data literacy.

\section{Step 4: Act, Data-Driven Management}

The previous steps show that data leads to information and information to knowledge through data analysis. Ultimately, it is about anticipating the insights that have been gained from this. The aim is to create an analytical model with predictive value, enabling strategic management. With the help of a data scientist, data can be converted, using machine learning and algorithms, into a predictive model. The explanatory characteristics and patterns from the previous step reveal opportunities and risks, and scenarios can be outlined. The tool forms the basis for deciding, intervening, and managing and in turn provides insight into the effects of these actions. It also functions as a monitor.

Here, the step is taken to actual data-driven management. Which policy changes do we consider necessary? And which actions are necessary to better utilize our real estate so that the objectives are achieved? Here, the leap is made to predictive and prescriptive analytics. The focus becomes more future-oriented. One point that certainly deserves attention in this step is that in data-driven management, there is a different perspective for action, including multidisciplinary collaboration, quick decision taking and actively taking action. If the insights obtained show that a certain (policy) adjustment or action is necessary, do we wait until a later moment in the cycle (with the risk that things have changed again) or can we make immediate adjustments (Feenstra, 2018)? Data-driven real estate management requires a certain freedom to act-fewer rules, less established routes, and discs through which decisions are taken — and more flexible cycles and real estate. How this should be realized and how we implement this are something that should become clear during the process.

Stakeholders for this fourth step are in any case Vastgoedbedrijf, Directie Maatschappelijke Ontwikkeling, Stadsontwikkeling and Onderzoek, Informatie \& Statistiek. Conditions are investing in data skills (data scientist), flexible organization, and flexible real estate. 


\section{Conclusion}

Data-driven real estate management is an innovative way of handling a changing environment and fits within a broader organizational line of data-driven working and managing. It requires a combination of the use of data and information technologies, organizational changes, and a different way of collaborating with internal and external parties (including citizens). A different government is expected, also called a smart government by Hiemstra (2015). The development involves a number of movements and shifts. Table 1 presents a depiction of a number of important changes to the municipality of Groningen.

Table 1

Shifts and Movements Through Data-Driven Working and Managing (Own Translation of Hiemstra)

\begin{tabular}{|c|c|c|}
\hline & Municipality of Groningen now & Municipality of Groningen 2019-2022 \\
\hline Organization & $\begin{array}{l}\text { Stand-alone units/departments (management, } \\
\text { policy, and implementation), hierarchy, internally } \\
\text { oriented }\end{array}$ & $\begin{array}{l}\text { Network of professionals, flexible project teams } \\
\text { based on knowledge and commitment, both } \\
\text { internally and externally }\end{array}$ \\
\hline Communication & Vertical, top-down, closed & $\begin{array}{l}\text { Horizontal and vertical, bottom-up and top-down, } \\
\text { transparent }\end{array}$ \\
\hline \multirow[t]{2}{*}{ Information } & Data to justify & Data to decide, realize, and innovate \\
\hline & Separate data (sets) and few links & $\begin{array}{l}\text { Smart combination of own data, Big Data, and } \\
\text { new data }\end{array}$ \\
\hline Policy creation & Long process (formulation and evaluation), inert & Short process, alert \\
\hline Influence & $\begin{array}{l}\text { Little; actual/nominal situation with black box in } \\
\text { between }\end{array}$ & $\begin{array}{l}\text { A lot; between reality and desirability there is } \\
\text { monitoring and adjustment }\end{array}$ \\
\hline Taking decisions & Ad hoc, reactive, experience-based & Foresighted, proactive, evidence-based \\
\hline Innovation & $\begin{array}{l}\text { Supports the existing way of thinking and } \\
\text { working }\end{array}$ & Is a driver for a new way of thinking and working \\
\hline $\begin{array}{l}\text { Data-driven working } \\
\text { and managing }\end{array}$ & Data revolution, selective use & Is a collective idea, part of the primary process \\
\hline
\end{tabular}

Data-driven working and managing is only partly about technology. An important theme in both this roadmap and for example in the smart-government idea is that both data-driven working and managing themselves and the process require a fundamentally different way of thinking and doing. There will be different skills, different ways of interacting, and different processes required. Among others, change experts Boonstra (2014) and Caluwé (2009) indicate that the culture of an organization is not an elusive phenomenon and is changeable as long as there is no imposed behavioural change. Telling people what to do from above and imposing what they must do are pointless. Allowing people to experience and do things for themselves (unconsciously) during a joint interactive process, such as via the step-by-step plan described above, does work. The path to data-driven real estate management is an example of doing, learning, and changing and can act as a catalyst for the overall organizational transition.

In line with this, the general programme of data-driven working and managing by municipalities is often developed according to the same pattern of innovation. "This pattern is that of (1) agenda-setting and coalition formation; (2) experimenting (...) with concrete projects; (3) broadening and embedding within the organization" (VNG, 2018). The VNG also notes that, nationally, no municipality is engaged in broadening and embedding. The front runners are engaged in several data pilots, especially within the social and public domain (quality of life, safety, self-reliance). Most of the municipalities are still in the first phase organization-wide. The city of Groningen has made strides in the form of a Chief Digital Officer who establishes the digital agenda and 
ensures joint orientation between market parties, knowledge institutions, and government (1). The team of the Digital Office, with two members of the municipality of Groningen, aims to initiate and encourage projects in the Northern Netherlands. There are several pilots and projects within the municipality of Groningen itself, and at the same time we are also working on agenda-setting and coalition building. Many things are happening at many different locations within the organization, but more direction is desirable. It is advisable as an expansion of or supplement to the Digital Office to start an internal, organization-wide programme including responsibility and budget ${ }^{3}$. The focus of the programme should in particular be on creating and safeguarding an organization-wide basis (including vision, rules, and data landscape) and knowledge accumulation and transfer (3). The process and data model with regard to data-driven real estate management can be seen as a concrete project (2) and shows the ambition of the municipality of Groningen with regard to data-driven services and work.

At the same time, the path to data-driven real estate management is not dependent on an organization-wide programme; the development within the Vastgoedbedrijf can be deployed now. The described step-by-step plan ensures that we become familiar with the use of data and information technologies and ultimately come to a tool that makes actionable insights possible. Data-driven management is a means to the higher goal (social returns). Performance can be analysed; interests and objectives can be fully considered and policies formed. The use of data and information technologies creates insight and forms the basis for entering into dialogue, taking decisions and setting long-term goals. "You are not guided by data, but driven in your actions" (VNG, 2018). If, for example, it turns out that the social goal set in advance will not achieved and there is a negative financial return, do we have to keep the building? And if the social goal is achieved, but there is a negative financial return, how do we intervene? Or if we look more broadly, is a facility planned at the right location or is the city or a neighbourhood asking (not literally) for this real estate? And if we anticipate future trends and patterns, which facilities do we consider necessary and how can we respond to that?

The path to data-driven working and managing is a long-term one. The first three steps form the basis; in step 4, the ultimate goal is achieved. Data-driven real estate management is a different way of thinking and doing and follows a process of experimenting, checking and acting (managing). In Figure 3, the process for the first three steps is plotted against time. For the data model, the starting point is to connect the available data, including financial and maintenance data. This insight already provides valuable information about financial returns and opportunities and threats, teaches us to (critically) handle data, and provides a stepping stone for further development. In a follow-up phase, the step is taken towards data-driven management. The outcome is a proactive, agile, future-proof organization that responds in an innovative way to a changing environment and manages for the highest possible social return.

\footnotetext{
3 The municipality of Utrecht, for example, works with a programme leader, a budget of two million Euros per year and an administrative objective of at least two projects in the area of data-driven management per organizational unit. The municipality of Haarlem has an internal Chief Data Officer who is responsible for municipality-wide policy and frameworks in the area of data management.
} 


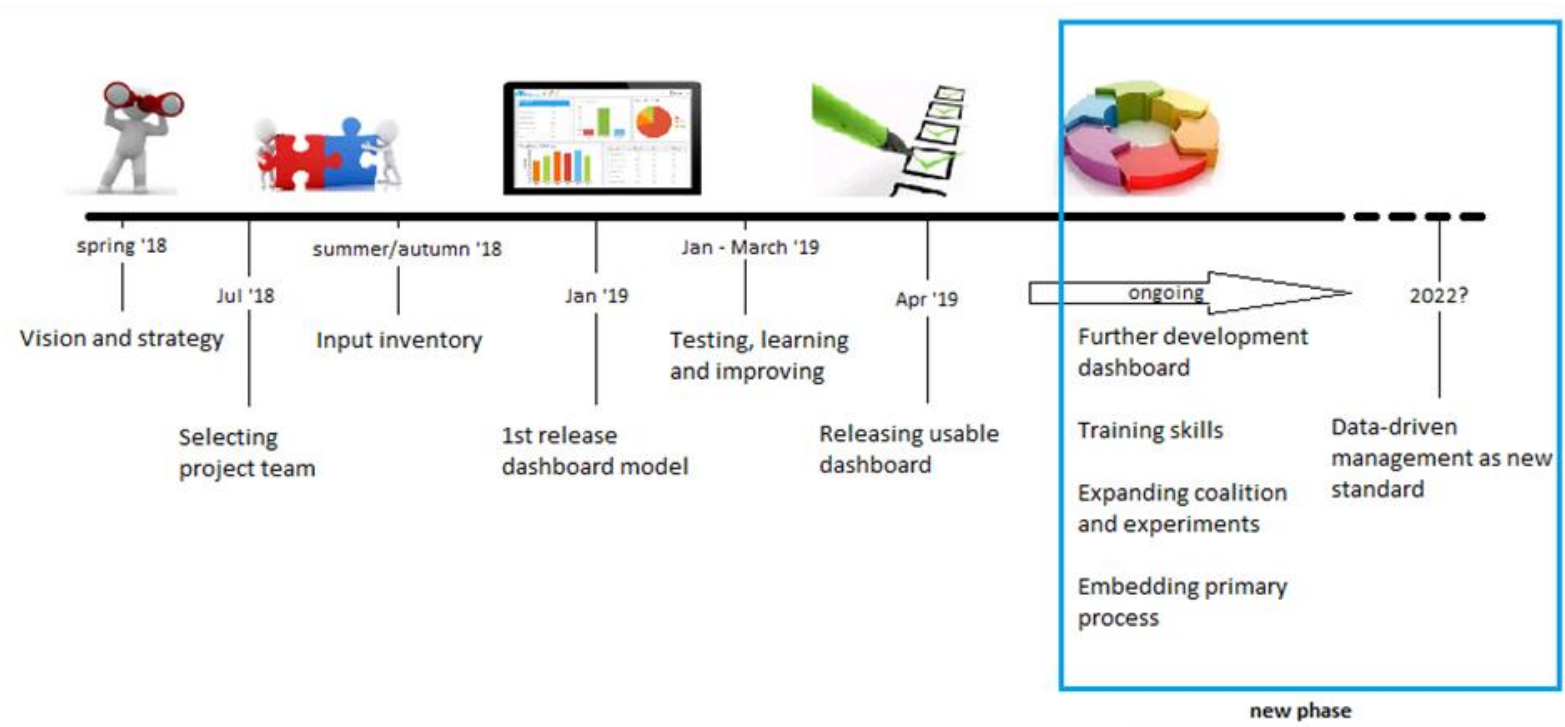

Developing vision and strategy (step 1)

Selecting project team based on consensus and commitment

Inventory of required input (step 2)

First release of dashboard model (step 2)

Testing, learning, and improving (step 3)

Release of usable dashboard (step 2)

Further development of dashboard (steps 1, 2, and 3)

Training skills and competencies (step 4)

Expanding coalition and experiments (step 4)

Embedding in primary process (step 4)

Figure 3. Time path for data-driven real estate management.

\section{References}

Boonstra, J. (2014). Leiders in cultuurverandering. Een praktische gids voor strategische en culturele veranderingen in organisaties (Leaders in cultural change. A practical guide for strategic and cultural changes in organizations). Assen: Koninklijke Van Gorkum BV.

Boonstra, J., \& Es, R. (2017). Veranderen van maatschappelijk organisaties. Praktische concepten en inspirerende praktijkverhalen (Changing social organizations. Practical concepts and inspiring practical stories). Amsterdam: Business Contact.

Caluwé, L. (2009). Culturen veranderen (Cultures change). M\&O Tijdschrift voor management en organisatie (M\&O Magazine for Management and Organization), 3, 113-123. Retrieved from http://www.decaluwe.nl/articles/CulturenVeranderen.pdf

Damhof, R. (2016). Maak datamanagement bespreekbaar in de hele organisatie (Make data management negotiable throughout organization).

Retrieved from https://www.scamander.com/nl/wp-content/uploads/2016/11/dutch-het-data-kwadranten-model-interview-ronald-damhof-1.pdf

Est, R., Bakker, E., Broek, J., Deuten, J., Diederen, P., Keulen, I., Korthagen, I., \& Voncken, H. (2018). Waardevol digitaliseren. Hoe lokale bestuurders vanuit publiek perspectief mee kunnen doen aan het "technologiespel" (Valuable digitization. How local drivers from a public perspective can participate in the "technology game”). The Hague: Rathenau Institute.

Feenstra, J. (2018). Visie \& kader datagedreven werken \& sturen (Vision \& framework for data-driven working and managing). Internal document and part of the vision on digitization and services.

Gemeente Groningen (Municipality of Groningen). (2017). Virtueel Groningen 2022. Groningen: Municipality of Groningen.

Hiemstra, J. (2015). Smart government: De noodzakelijke stap in organisatievernieuwing van de publieke sector (Smart government: The necessary step in organizational innovation of the public sector). Retrieved from http://www.smartgovernment.nl/download/artikelen/vernieuwingpubliekesector.pdf 
Klous, S., \& Wielaard, N. (2014). Wij zijn Big Data. De toekomst van de informatiesamenleving (We are Big Data. The future of the information society). Amsterdam: Business Contact.

Kool, L., Timmer, J., \& Est, R. (2015). De datagedreven samenleving-Achtergrondstudie (The data-driven society—Background study). The Hague: Rathenau Institute.

Veuger, J. (2013). Denken in waarden. Een op waarden gebaseerde vastgoedstrategie stelt de onderneming in staat een competitieve strategie aan te gaan (Thinking in values. A real estate strategy based on values enables the company to adopt a competitive strategy). Groningen: Knowledge Centre NoorderRuimte Hanze University of Applied Sciences.

Veuger, J. (2017). Een wendbare vastgoedeconomie met Disruptie en Blockchain (An agile real estate economy with Disruption and Blockchain). Groningen: Knowledge Centre NoorderRuimte Hanze University of Applied Sciences.

VNG. (2018). Datagedreven sturing bij gemeenten. Van data tot (gedeelde) informatie voor beter (samen) sturen (Data-driven management at municipalities. From data to (shared) information for better (co-)management). Retrieved from https://vng.nl/files/vng/nieuws_attachments/2018/datagedreven_sturing_bij_gemeenten_lr.pdf

Wildenberg, W. (2017). Op weg naar toekomstbestendig gemeentelijk vastgoed. Van centralisatie en basis op orde naar strategische portefeuillesturing (Towards future-proof municipal real estate. From centralization and basically in order to strategic portfolio management). In 10 jaar Barometer Maatschappelijk Vastgoed; impact, trends en ontwikkelingen (10-year Barometer of Social Real Estate: Impact, trends and developments) (pp. 93-104). Groningen: Veuger, Sleen. 